\section{Effect of Transplanting on Earliness and Total Yield of Watermelon}

\author{
Stephen M. Olson', \\ George J. Hochmuth', and \\ Robert C. Hochmuth ${ }^{3}$
}

Additional index words. Citrullus lanatus, direct-seeding

Summary. Studies were conducted at the NFREC, Quincy, and AREC, Live Oak, Fla., to compare watermelon $\{$ Citrullus lanatus [(Thumb.) Matsum \& Nakai] \} plant establishment by transplanting and direct-seeding. Cultivars used were 'Charleston Gray' in $1984,1985,1986$, and 1989; 'Jubilee' in 1988 and 1989; and 'Crimson Sweet' in 1987 to 1990. Early yields were greater with transplants for all three cultivars in all years. With 'Charleston Gray', total yields with transplants were higher in 1985 and 1989, but not in 1984 or 1986. The average fruit weights with transplants were also greater in 1985 and 1989 than in 1984 or 1986. With 'Jubilee', total yield with transplants was higher in 1989, but not in 1988. Average fruit weight with transplants was greater in 1989 than in 1988. With 'Crimson Sweet', total yields were higher with transplants in 1989 and 1990, but not in 1987 or 1988, but fruits were larger with transplanting compared to direct-seeding only in 1990. In all experiments, yields with transplants were never less than those with direct-seeded plants.

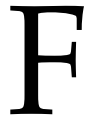
lorida is the leading watermelonproducing state in the United States. Watermelons were grown

Florida Agricultural Experiment Station Journal Series $R-02718$. The cost of publishing this paper was defrayed in part by the payment of page charges. Under postal regulations, this paper therefore must be hereby marked advertisement solely to indicate this fact.

${ }^{1}$ Associate Professor, North Florida Research and Educa tion Center, University of Florida, Route 3, Box 4370, Quincy, FL 32351.

${ }^{2}$ Professor, Horticultural Sciences Department, University of Florida, Gainesville, FL 32611.

${ }^{3}$ Multicounty Extension Agent II, Suwannee Valley Research and Education Center, University of Florida, Live Oak, FL 32060. on $=21,500$ ha and were worth about $\$ 62.5$ million in the 1991-92 production season (Florida Agricultural Statistics Service, 199 3). Traditionally, watermelons have been direct-seeded because planting is easier and seed costs are low. Also, most of the watermelons in Florida have been produced without mulch. As growers have adapted to production on polyethylene mulch, methods of crop establishment have changed. Some of the advantages of transplanting include: 1 ) reduced seed requirements (a benefit with expensive hybrids or seedless cultivars); 2) potentially earlier harvests; 3) occasional increase in total yield; and 4) more-precise stand establishment, which is necessary for uniform fruit size. In addition, transplants are more satisfactory for production of seedless watermelons due to their poor seed germination under field conditions.

In muskmelons, early yields (Brown and Osborn,1989; Wiedenfeld et al., 1990) and total yields (Brown and Osborn, 1989) are increased with transplants compared to direct-seeded plants. Berle et al., (1988) found no difference in yield (number/ha) when transplanted or direct-seeded muskmelons were produced on black polyethylene-mulched beds. In a 4-year study using 'Crimson Sweet' watermelons, Hochmuth et al. (1991) reported higher early yields each season when using transplants and higher total yields in 2 of 4 years. Hall (1989) reported higher total yield with transplants for 'Charleston Gray', but not with 'Crimson Sweet' watermelons. Other researchers (Vavrina et al., 1990) using 'Crimson Sweet' have shown higher yields of first-harvest fruits when using transplants, but not in total yields or fruit size. Transplanting has not been reported to result in a decrease in yield, but it often has resulted in higher total yields compared to direct-seeded plants.

This study was done to clarify the benefit of using transplants of several cultivars in two watermelon production areas of Florida.

\section{Materials and methods}

Quincy. Watermelons were grown on Dothan loamy fine sandy (fine-loamy, siliceous, thermic Typic Kandiudult) soils during 1984 to 1989. Beds were fumigated only in 1988 and 1989 with $267 \mathrm{~kg} \cdot \mathrm{ha}^{-1}$ of a 98 methyl bromide : 2 chloropicrin mixture as beds were mulched. All fertilizer was applied preplant in a modified broadcast under the mulch. Rates used (in 
$\mathrm{kg} \cdot \mathrm{ha}^{-1}$ ) of N-P-K were 157-70-100 in 1984, 134-36-132 in 1985 through 1988, and 16845-141 in 1989. Beds on 3-m centers with 91-cm tops were covered with black polyethylene mulch (0.032 mm) each year. Cultivars used were 'Charleston Gray' in 1984, 1985 , 1986, and 1989 and 'Jubilee' in 1988 and 1989. Transplants were grown in Todd 150 planter flats (Speedling Inc., Sun City, Fla.) with cell dimensions of $38 \mathrm{~mm} \times 38 \mathrm{~mm}$ and $64 \mathrm{~mm}$ deep. Flats were filled with a peat-lite media (Metro Mix 220, Grace Sierra, Milpitas, Calif.) and seedlings were grown for 5 weeks before transplanting. Direct-seeding was done by mixing the seed in "plug-mix" (fine peat/vermiculite) medium and placing $\approx 120 \mathrm{~cm}^{3}$ of the seed mix at each hill in the field at the same time as transplanting. Planting dates were 28 Mar. 1984 and 1985, 27 Mar. 1986, 22 Mar. 1988, and 29 Mar. 1989. In-row spacing was $102 \mathrm{~cm}$ in 1984, 1985, and 1986 and $91 \mathrm{~cm}$ in 1988 and 1989. Plots were irrigated with overhead sprinkler system in 1984, 1985, 1986, and 1988 and drip system in 1989. Labeled pesticides were applied for disease and insect control.

A randomized complete-block design experiment with four replications was used. Marketable yield (fruits $>6.8$ $\mathrm{kg}$ ) and fruit weight and number were determined. There were three harvests in 1984, 1985, and 1986 and four harvests in 1988 and 1989. In 1989, notations also were made as to the number of fruit touching the mulched bed.

Live Oak. Watermelons were grown on Lakeland fine sand (thermic, coated Typic Quartzipsamment) soil during 1987 to 1990 at AREC, Live Oak. Fertilizer was applied at a rate of $146 \mathrm{~N}-20 \mathrm{P}-121 \mathrm{~K}\left(\mathrm{~kg} \cdot \mathrm{ha}^{-1}\right)$ in each production year. Beds on 2.25-m centers were fumigatedwith $336 \mathrm{~kg} \cdot \mathrm{ha}^{-1}$ of a 98 methyl bromide : 2 chloropicrin mixture and covered with black polyethylene mulch $(0.032 \mathrm{~mm})$. Bed width was $91 \mathrm{~cm}$ in each production year, except 1990, when bed width was $61 \mathrm{~cm}$. 'Crimson Sweet' was used each year. Transplants from a commercial transplant producer were 4 weeks old from seeding when planted in the field. Planting dates were 20 Mar. in 1987 and 1990, 24 Mar. 1988, and 22 Mar. 1989. In-row spacing was $46 \mathrm{~cm}$ in 1988 and $91 \mathrm{~cm}$ in 1987, 1989, and 1990. For direct-seeding in 1987 and 1988 , seeds were mixed in plug-mix media and planted in the field at the same time as transplanting. Plug-mix media was not used in 1989 and 1990.
Drip irrigation was used in each production year.

Treatments were arranged factorially in a randomized completeblock design experiment with four replications in 1987 and 1990 and three replications in 1988 and 1989. Marketable yield (fruit $>5.5 \mathrm{~kg}$ ) and fruit weight and number were determined. Numbers of harvests were four in 1987 and 1990 and three in 1988 and 1989.

\section{Results}

Quincy, 'Charlestom Gray'. Early fruit yields were significantly ( $P \leq$ 0.05 ) higher from transplants during all years except 1984 ( $P=0.09)$ (Table 1). Total yields were significantly higher from transplants in 2 of the 4 years (Table 1). In 1984 and 1986, total yields from transplants and directseeded plots were not significantly different. Total yields in these 2 years were also lower than expected due to severe infection with watermelon mosaic virus II. Infection occurred early in both years, and symptoms were visible on both foliage and fruit.

The fruit weights followed the same pattern as total yield, with larger fruit occurring with transplants in 1985 and
1989 (Table 1). There was no significant effect of transplanting on average fruit weight in 1984 or 1986. This again may have been due to the stress brought about by the virus infection.

Quincy, 'Jubilee'. The transplanted watermelons produced significantly higher early yields than the direct-seeded watermelons (Table 2). Transplanted watermelons also produced significantly higher total yields in 1989 than the direct-seeded watermelons, but not in 1988 (Table 2). Again, average fruit weights followed the same pattern as the total yields, with no significant differences in 1988. In 1989, average fruit weights were significantly higher from transplanting than from direct-seeding (Table 2).

In 1989, in 'Charleston Gray' and 'Jubilee', observations were recorded as-to how many of the fruits were on or touching the mulched bed (Table 3). An assumption was made that vines would grow at random and fruit set would be at random. A significantly higher percentage of fruit were touching the mulch from transplants (74\%) compared to direct-seeded plants (51\%). Percentage of fruit from 'Charleston Gray' touching mulch (77\%) was

Table 1. Influence of planting method on early and total yields and fruit weight of 'Charleston Gray' watermelons, NFREC, Quincy, Fla.

\begin{tabular}{|c|c|c|c|c|}
\hline \multirow{2}{*}{$\begin{array}{l}\text { Planting } \\
\text { method }\end{array}$} & \multicolumn{4}{|c|}{ Production season } \\
\hline & 1984 & 1985 & 1986 & 1989 \\
\hline & \multicolumn{4}{|c|}{ Early yield $\left(\mathrm{Mg} \cdot \mathrm{ha}^{-1}\right)$} \\
\hline Transplanted & 29.7 & 43.3 & 18.7 & 37.7 \\
\hline \multirow[t]{3}{*}{ Direct-seeded } & 16.3 & 17.5 & 4.2 & 15.3 \\
\hline & NS $(0.09)$ & & & $* *$ \\
\hline & \multicolumn{4}{|c|}{ Total yield $\left(\mathrm{Mg} \cdot h \mathrm{ha}^{-1}\right)$} \\
\hline Transplanted & 40.0 & 74.7 & 42.8 & 49.0 \\
\hline \multirow[t]{3}{*}{ Direct-seeded } & 39.6 & 54.5 & 43.0 & 31.6 \\
\hline & NS & & NS & \\
\hline & \multicolumn{4}{|c|}{ Fruit wt $(\mathrm{kg})$} \\
\hline Transplanted & 8.4 & 11.1 & 9.9 & 12.2 \\
\hline \multirow[t]{2}{*}{ Direct-seeded } & 8.6 & \multirow{2}{*}{9.7} & 9.6 & \multirow{2}{*}{$\underset{* *}{10.9}$} \\
\hline & NS & & NS & \\
\hline
\end{tabular}

Table 2. Yields of 'Jubilee' watermelon as influenced by planting method, NFREC, Quincy, Fla.

\begin{tabular}{|c|c|c|c|c|c|c|}
\hline \multirow{4}{*}{$\begin{array}{l}\text { Planting } \\
\text { method }\end{array}$} & \multicolumn{6}{|c|}{ Production season } \\
\hline & \multicolumn{3}{|c|}{1988} & \multicolumn{3}{|c|}{1989} \\
\hline & \multicolumn{2}{|c|}{ Yields $\left(\mathrm{Mg} \cdot \mathrm{ha}^{-1}\right)$} & \multirow{2}{*}{$\begin{array}{c}\text { Fruit wt } \\
(\mathrm{kg})\end{array}$} & \multicolumn{2}{|c|}{ Yields $\left(\mathrm{Mg} \cdot \mathrm{ha}^{-1}\right)$} & \multirow{2}{*}{$\begin{array}{c}\text { Fruit wt } \\
(\mathrm{kg})\end{array}$} \\
\hline & $\overline{\text { Early }^{2}}$ & Total & & Early & Total & \\
\hline Transplanted & 12.8 & 34.1 & 12.5 & 31.8 & 49.4 & 13.8 \\
\hline \multirow[t]{2}{*}{ Direct-seeded } & \multirow{2}{*}{$\begin{array}{l}3.2 \\
*\end{array}$} & 29.9 & 13.0 & \multirow{2}{*}{$\mathbb{*}_{*} 17.5$} & \multirow{2}{*}{${ }_{* *}^{33.6}$} & \multirow{2}{*}{$1 \underset{* *}{2.5}$} \\
\hline & & NS & NS & & & \\
\hline
\end{tabular}

Early yields include first two harvests.

Significant at $\mathrm{P}=0.05,0.01$, or not significant, respectively. 
Table 3. Main effects of planting method and cultivars on numbers of fruit touching. polyethylene-mulched bed during 1989 production year, NFRBC, Quincy, Fla.

\begin{tabular}{lc}
\hline Treatment & $\begin{array}{c}\text { Fruit in contact } \\
\text { with mulch (\%) }\end{array}$ \\
\hline Planting method (PM) & \\
Transplants & 74 \\
Direct-seeded & 51 \\
Significance & $*$ \\
Cultivar (C) & \\
Charleston Grey & 77 \\
Jubilee & 48 \\
Significance & $* *$ \\
RM $\times$ C & \\
\hline Significant at $\mathrm{P}=0.05,0.01$, or not signifi-
\end{tabular}

cant, respectively.

significantly higher than fruit of 'Jubilee' $(48 \%)$. There was no interaction of cultivar and planting method for percentage of fruit touching the mulch.

Live Oak, 'Crimson Sweet'. Watermelons established from transplants produced higher early yields than from direct-seeded plants in all four production years (Table 4 ). Total yields were not affected significantly by planting method in 1987 or 1988, but, in 1989 and 1990, yields from transplants were significantly higher than from directseeded plants (Table 4). Average fruit weights were significantly greater for transplants only in 1990 (Table 4).

\section{Discussion}

In these studies, earliness was enhanced consistently by transplanting compared to direct-seeding. In nine out of 10 cultivar/year combinations, transplanting produced significantly higher early yields than plants grown from direct-seeding. Earliness results in higher profitability (Meline and Hochmuth, 1988), and justifies the use of transplants for watermelon production where earliness is desired, even though production cost is higher (\$181/ha) when transplants are used (Table 5). When hybrid seed is used, the cost difference per hectare in the two planting systems is reduced from $\$ 181$ to $\$ 113$ (Table 5).

Total fruit yields from transplants were higher in nine of 10 cultivar/year combinations, but were significantly higher in only five of the combinations. Transplanting in these studies produced higher yields $50 \%$ of the time, with a range of increase of $37 \%$ to $57 \%$, depending upon cultivar/year combination. These findings are consistent with those of other researchers (Hall,1989; Hochmuth et al.,1991; Vavrina et al.,1990). The increase in yields with transplants could be due to an increase in fruit set closer to the crown. In 1989, at the Quincy location, fruit from transplants of both 'Charleston Gray' and 'Jubilee' were larger than those from direct-seeded plants (Tables 1 and 2). Also, in this production season, more fruit from transplants of both cultivars were touching the mulched bed than those from direct-seeded plants, suggesting that more fruit had set closer to the crown of the plant. In this study, the increase in fruit size maybe the result of fruit set closer to the crown and may help explain why yield increases sometimes may occur with transplants. The results of this series of studies clearly show the benefit that growers would realize from using transplants in their production program.

Table 4, Influence of planting method on early and total yields and fruit weight of 'Crimson Sweet' watermelons, AREC, Live Oak, Fla.

\begin{tabular}{|c|c|c|c|c|}
\hline \multirow{2}{*}{$\begin{array}{l}\text { Planting } \\
\text { method }\end{array}$} & \multicolumn{4}{|c|}{ Production season } \\
\hline & 1987 & 1988 & 1989 & 1990 \\
\hline & \multicolumn{4}{|c|}{ Early yield $\left(M g \cdot h a^{-1}\right)$} \\
\hline Transplanted & 34.6 & 32.7 & 43.1 & 40.0 \\
\hline Direct-seeded & $\underset{* *}{7.1}$ & 19.8 & $\begin{array}{l}0.0 \\
* *\end{array}$ & $\begin{array}{l}8.5 \\
* *\end{array}$ \\
\hline \multicolumn{5}{|c|}{ Total yield $\left(M g \cdot h a^{-1}\right)$} \\
\hline Transplanted & 62.4 & 49.6 & 60.9 & 100.3 \\
\hline Direct-seeded & 58.1 & 37.1 & 42.8 & 63.6 \\
\hline & \multicolumn{4}{|c|}{ NS $(0.08)$} \\
\hline & \multicolumn{4}{|c|}{ Fruit wt $(\mathrm{kg})$} \\
\hline Transplanted & 10.2 & 7.4 & 7.7 & 9.0 \\
\hline \multirow[t]{2}{*}{ Direct-seeded } & 9.2 & 6.7 & 6.8 & 8.1 \\
\hline & NS & NS & NS $\quad(0.11)$ & ** \\
\hline
\end{tabular}

"Early yield is comprised of the first two harvests in 1987, 1988, and 1989 and the first harvest in 1990. "Significant at $\mathrm{P}=0.05,0.01$, or not significant, respectively.

Table 5. Estimated cost differences per hectare associated with transplanting and directseeding of watermelons.

\begin{tabular}{lcr}
\hline & \multicolumn{2}{c}{ Costs $^{\mathrm{y}}$} \\
\cline { 2 - 3 } Item & \multicolumn{3}{c}{ Transplants } & Direct \\
\hline Transplants & & \\
$\quad(\$ 36 / 1000)$ & $\$ 162.00$ & --- \\
Seed & & \\
$\quad(\$ 26.40 / \mathrm{kg})$ & 13.20 & $26.40^{\mathrm{w}}$ \\
Labor & & \\
$\quad$ Transplant and & & \\
$\quad$ reset & 59.60 & --- \\
$\quad$ Direct-seeding & --- & 5.60 \\
$\quad$ Thinning & & 27.70 \\
Equipment & & \\
$\quad$ Transplanting & 14.10 & \\
$\quad$ Direct-seeding & -- & $8.20^{\prime \prime}$ \\
Total & $\$ 248.90$ & $\$ 67.90$
\end{tabular}

${ }^{2}$ Adapted from Smith and Taylor (1993). "Based on 4500 plants/ha $\left(2.22 \mathrm{~m}^{2} /\right.$ plant $)$.

${ }^{x}$ Based on using open-pollinated seed; if using hybrid seed (2N), cost increases would be $\$ 68$ and $\$ 136 /$ ha for transplanted and direct-seeded, respectively.

${ }^{w}$ Based on planting two seeds per bill using a large-seeded cultivar.

\section{Literature Cited}

Berle, D., E.A. Estes, D.C. Sanders, and W.J. Lament. 1988. Economic evaluation of different cultural systems for muskmelon production. HortScience 23:324-326.

Brown, J.E. and M.C. Osborn. 1989. Optimizing planting methods for an intensive muskmelon production system. HortScience 24:149.

Florida Agricultural Statistics Service. 1993. Florida agricultural statistics, vegetable summary 1990-1991. Fla. Agr. Stat. Serv., Orlando.

Hall, M.R. 1989. Cell size of seedling containers influences early vine growth and yield of transplanted watermelon. HortScience 24:771-773.

Hochmuth, R.C., G.J. Hochmuth, and M.E. Donley. 1991. Polyethylene mulch and transplants increase early watermelon production in north Florida. Univ. Fla. Coop. Ext. Rpt., Suwannee Valley AREC 91-10.

Meline, C.D. and G.J. Hochmuth. 1988. Economics of watermelon and muskmelon planting systems in north Florida. Proc. Fla. State Hort. Soc. 101:404-407.

Smith, S.A. and T.G. Taylor. 1993. Production cost for selected vegetables in Florida, 19911992. Fla. Coop. Ext. Serv. Circ. 1064.

Vavrina, C.S., K. Armbrester, and T.B. Cole. 1990. Watermelon production as influenced by transplant age. Proc. Fla. State Hort. Soc. 103:94-96

Wiedenfeld, R., E. Hinojosa, and R. Stubblefield. 1990. Plant method, ground cover and irrigation level effects on muskmelon production. HortScience 25:863. (Abstr.) 